\title{
Effect of Aspirin on Maturation of Arteriovenous Fistula Created for Hemodialysis in End Stage Renal Disease Patients
}

\author{
NADER M. HAMADA, M.D.*; SHAABAN M. ABDEL-MAGEED, M.D.**; HISHAM M. OMRAN, M.D.** and \\ YASSER H. EMARA, M.Sc.*
}

The Departments of Vascular Surgery* and General Surgery**, Faculty of Medicine, Ain Shams University

\begin{abstract}
Background: With the increasing prevalence of End stage renal disease (ESRD) there is a growing need for Hemodialysis (HD). Safe, durable and reliable vascular access is essential for successful HD but failure of maturation continue to present significant barriers to successful fistula use. The study was conducted on 50 patients to assess the effect of aspirin on maturation of radio-cephalic arteriovenous fistula (RC-AVF).

Aim of Study: To assess the effect of Aspirin on the maturation of RC-AVF versus non treatment group.

Patients and Methods: This study was conducted on fifty ESRD patients who had a RC-AVF in either Ain Shams University Hospitals or El Sahel Teaching Hospital from September 2019 to March 2020. We have included all patients who had an RC-AVF under local anesthesia and the fistula was clinically functioning immediately post operatively. The study is a prospective randomized controlled trial (RCT) comparing Aspirin intake versus no treatment in patients who had a functioning RC-AVF after finishing creation of the fistula. The patients in the first group was given aspirin (ASA) $75 \mathrm{mg}$ tablet once daily after AVF creation for six weeks postoperatively, while the patients in the second group did not receive any medication.
\end{abstract}

Results: After Six weeks of follow-up of all patients, maturation occurred in $94 \%$ of patients. The maturation rate in Apirin group was $96 \%$, while it was $92 \%$ in control group with a $p$-value of 0.5743 . Access thrombosis has occurred in one patient in the aspirin group and two patients in the control group with a $p$-value of 0.327 .

The mean flow volume was $780 \mathrm{ml} / \mathrm{min} \pm 127.2$ in the aspirin group and $754.4 \mathrm{ml} / \mathrm{min} \pm 128.9$ in the control group with a $p$-value $=0.484$. The mean vein diameter in aspirin group was $5.86 \mathrm{~mm} \pm 0.342$ and that of the control group was $5.992 \mathrm{~mm} \pm 0.287$ with a $p$-value $=0.284$.

Conclusion: Aspirin use was not beneficial for AVF maturation among ESRD patients who undergo a new RCAVF. That's why practice patterns in this area needs to be improved to limit unbeneficial aspirin use.

Key Words: Radio-cephalic arteriovenous fistula - Aspirin Maturation - End-stage renal disease.

Correspondence to: Dr. Yasser H. Emara, E-Mail: Yasseremara91@gmail.com

\section{Introduction}

WITH the increasing prevalence of End stage renal disease (ESRD) there is a growing need for Hemodialysis (HD) [1]. Safe, durable and reliable vascular access is essential for successful HD but failure of maturation continue to present significant barriers to successful fistula use [2]. Long term patency rates of native arteriovenous fistula (AVF) has the best outcome compared to other methods e.g. synthetic grafts and double lumen catheters [3] Autogenous AVF also has the lowest cost and the lowest infection rate. Radio cephalic autogenously arteriovenous fistula (RC-AVF) is the first choice for vascular dialysis. This is a logical choice, as further fistulae can be created proximally if needed (i.e. brachio-cephalic/basilic fistula) and the risk of steal syndrome is reduced [4].

Several researches tried to improve the patency and maturation of arterio-venous access (AVA) by administering different drugs. Their studies have discussed the effect of drugs like (aspirin, ticlopidine, dipyridamole, dipyridamole plus aspirin, warfarin, fish oil, clopidogrel, and sulfinpyrazone) on patency and maturation of AVA. Aspirin is the most commonly used antiplatelet agent [5]. It depends on the irreversible inhibition of arachidonate cyclo-oxygenase activity in platelets, thereby reducing the extent of thromboxane A2 (TXA2) formation and consequently the aggregability of platelets [6]. Aspirin is suggested as medical therapy, which potentially inhibits neointimal hyperplasia and improves vascular access patency [7]. However, the effect of aspirin has not been adequately evaluated with respect to vascular access maturation.

Aim of the work:

The aim of this study is to assess the effect of Aspirin on the maturation of a functioning RCAVF versus non-treatment group. 


\section{Patients and Methods}

The study is a prospective randomized controlled trial (RCT) comparing Aspirin intake versus no treatment in End stage renal disease (ESRD) patients who had a functioning RC-AVF after creation of the fistula. The study was conducted on patients who had ther RC-AVF surgery in either Ain Shams University Hospitals or El Sahel Teaching Hospital - from September 2019 to March 2020.

We have included 50 patients who had a RCAVF, which was functioning clinically just after the fistula creation. The fistula was described to be functioning by the presence of palpable thrill and audible bruit over it. Patients were divided into two groups:

The $1{ }^{\text {st }}$ group (treatment group)-included 25 patients-received Aspirin, acetylsalicylic acid (ASA) $75 \mathrm{mg}$ tablet once daily from day one after AVF creation for 6 weeks, while the 2 nd group (control group)-included 25 patients-did not receive any medication. After two and six weeks the two groups were examined clinically and radiologically for fistula maturation \& presence of complications.

\section{Inclusion criteria:}

All adult mentally competent patients with ESRD who had a functioning radio-cephalic AVF (RC-AVF) done under local anaesthesia for haemodialysis were included in the study if they agree to participate \& signed the detailed consent form.

\section{Exclusion criteria:}

- Patients who refused to be enrolled or randomised in the study.

- Age below 18 years.

- Patients with a known bleeding disorder.

- Pregnant \& lactating female patients.

- Active peptic ulcer disease.

- Severe hepatic insufficiency.

- Patients who are on antiplatelet or anticoagulation.

- Patients who already have a known allergy to aspirin.

- Patients who are not suitable for RC- AVF due to technical issues such as: Small-cephalic vein diameter $<2.5 \mathrm{~m}$-or thrombosed cephalic vein bilaterally, weak radial pulse or positive Allen test or radial artery diameter $<2 \mathrm{~mm}$ and

- Patients who are not candidate for AVF due to their general condition such as: Unwell on the day of the surgery, can't lie on operating table during the surgery and patients with heart failure.

- Patients with known central venous stenosis or occlusion on the side of the intended AVF creation.

\section{Methods:}

\section{Patient evaluation:}

Full history taking, clinical examination, radiological assessment of cephalic vein and radial artery and laboratory tests were done to all patients.

Full history taking included age, gender, history of hypertension (HTN), smoking, diabetes mellitus (DM), congestive heart failure (CHF), hepatic insufficiency, allergy to aspirin and administration of antiplatelet or anticoagulation. Clinical examination included examination of arterial pulses, measuring brachial systolic pressure bilaterally, examination of upper limb superficial veins, assessment of their course \& straightness, identification of the presence of venous collaterals over shoulder or anterior chest wall or upper arm and assessment of motor power and sensory examination. Laboratory investigation required for the procedure-complete blood count, random blood sugar, INR, liver enzymes, electrolytes and arterial blood gases-were done.

Preoperative duplex ultrasound vascular mapping was done to identify the best suitable vein for the autogenous RC-AVF.

All patients who were included signed an informed consent and agreed to attend the followup visits after the procedure. The consent included an explanation of the nature of the intended procedure and Aspirin administration, benefits and all the possible complications.

The fifty RC-AVF were created by vascular surgeons. The selected vein was marked on the skin. The surgical technique was standardized as follows:

- The Local anesthesia (lidocaine 2\%) was infiltrated with a dose of $4.5-5 \mathrm{mg} / \mathrm{kg}$ not exceeding $300 \mathrm{mg}$ and then a $3-5 \mathrm{~cm}$.

- A longitudinal skin incision in the distal forearm between the radial artery and the cephalic vein closer to the artery as it is deeper $\&$ more difficult to mobilize was done.

- Cephalic vein was dissected ( $5 \mathrm{~cm}$ segment), divided, the distal end and tributaries of the vein were ligated using 2-0 silk and the vein was gently distended with heparinized saline. 
- The radial artery was dissected until a segment of the artery was isolated for proximal and distal control ( $3 \mathrm{~cm}$ segment).

- A 10-12mm longitudinal anterior arteriotomy was done by using a scalpel size 11 and Potts scissors.

- Both vessels were prepared for the anastomosis. Vein to artery anastomosis: Posterior venotomy was performed then cephalic vein was moved medially over the artery and the fistula was created between the posterior aspect of the vein (underside of the vein) and the anterior (upper) aspect of the artery with a 6.0 polypropylene.

- The skin closure was done using 3.0 polypropylene sutures.

- The fistula was then examined for presence of palpable thrill and audible bruit.

All patients were instructed to do exercise by using rubber ball three times daily-each time ten minutes- for six weeks and to avoid using the upper limb of the AVF for blood pressure measurement, blood sampling or IV line insertion/injections. All functioning AVFs were examined clinically intraoperative, two and six weeks post-operatively for the presence of palpable thrill and audible bruit. Duplex follow-up for diameter of the vein, depth from skin and flow volume was done two and six weeks post-operatively. The first cannulation of the RC-AVF was performed once the vein had matured adequately (usually six to twelve weeks after surgery). Primary outcome was the RC-AVF maturation. Maturation was determined clinically by the presence of palpable thrill and audible bruit over the AVF after at least 6 weeks of creation and radiologically by duplex US. Radiological criteria of maturation was defined as cephalic diameter at the anastomosis $\geq 6 \mathrm{~mm}$ and flow of the blood across the anastomosis $\geq 500 \mathrm{ml} / \mathrm{minute}$. Secondary endpoints were presence of complications: Such as: Bleeding, infection, stenosis, thrombosis, distal limb ischemia and Mortality.

Patients were randomized using closed envelopes method. Every patient has chosen a closed envelope to indicate the group he will be allocated to (either the first group or the second group).

\section{Statistical analysis:}

Recorded data were analyzed using the statistical package for social sciences, version 20.0 (SPSS Inc., Chicago, Illinois, USA). Quantitative data were expressed as mean \pm standard deviation (SD). Qualitative data were expressed as frequency and percentage. Probability ( $p$-value): $* p$-value $\leq 0.05$ was considered significant, $* * p$-value $\leq 0.001$ was considered as highly significant, $p$-value $>0.05$ was considered insignificant.

\section{Results}

The study included 50 ESRD patients who came to the Vascular Surgery Department at Ain Shams University Hospitals and El Sahel Teaching Hospital for AVF creation under the supervision of thesis supervisors from September 2019 to March 2020. We have included all patients who had an RC-AVF under local anesthesia and the fistula was clinically functioning immediately post operatively. Patients were divided into two groups: The 1 st group (treatment group)-included 25 patientsreceived Aspirin, acetylsalicylic acid (ASA) $75 \mathrm{mg}$ tablet once daily after AVF creation for 6 weeks, while the 2 nd group (control group)-included 25 patients- did not receive any medication. After two and six weeks the two groups were examined clinically and radiologically for fistula maturation.

The mean age of patients in the aspirin group was $56.08 \pm 11.7$ years and that of the control group was $54.56 \pm 13.9$ years with a $p$-value of 0.759 . Among the patients included in the study, four of them were found to be current smokers. As regard diabetes, $28 \%$ were diabetic. Hypertensive patients represented $86 \%$ of the patients. The number of patients who were referred before the start of dialysis was six patients. The demographic characteristics and risk factor distribution are shown in (Table 1) and there was no statistically significant difference between both groups among demographics.

Table (1): Comparison between groups according to demographic data.

\begin{tabular}{|c|c|c|c|}
\hline $\begin{array}{l}\text { Demographic } \\
\text { data }\end{array}$ & On Aspirin & $\begin{array}{l}\text { Not on } \\
\text { Aspirin }\end{array}$ & $\begin{array}{c}p- \\
\text { value }\end{array}$ \\
\hline \multicolumn{4}{|l|}{ Age: } \\
\hline Mean $\pm(S D)$ & $56.08 \pm(11.7)$ & $54.56 \pm(13.9)$ & 0.759 \\
\hline Range & $30-80$ & $25-88$ & \\
\hline \multicolumn{4}{|l|}{ Gender: } \\
\hline Male & $9(36 \%)$ & $12(48 \%)$ & 0.417 \\
\hline Female & $16(64 \%)$ & $13(52 \%)$ & \\
\hline Current smokers & $1(4 \%)$ & $3(12 \%)$ & 0.177 \\
\hline Hypertensive & $21(84 \%)$ & $22(88 \%)$ & 0.327 \\
\hline Diabetics & $8(32 \%)$ & $6(24 \%)$ & 0.161 \\
\hline
\end{tabular}

RC-AVF was done in the non-dominant hand of 28 patients. The mean preoperative cephalic vein $(\mathrm{CV})$ diameter was 2.828 with $\mathrm{SD} \pm 0.25$ in the aspirin group and 2.776 with $\mathrm{SD} \pm 0.27$ in the control group with a $p$-value of 0.626 . The Mean preoperative radial artery (RA) diameter was 2.18 $\mathrm{mm}$ with $\mathrm{SD} \pm(0.19)$ in the aspirin group and 2.26 $\mathrm{mm}$ with $\mathrm{SD} \pm(0.17)$ in the control group with a $p$-value 0.218 (Table 2). 
Table (2): Comparison between groups according to preoperative $\mathrm{CV}$ and $\mathrm{RA}$ diameter.

\begin{tabular}{llccc}
\hline \multirow{2}{*}{ Variables } & \multicolumn{2}{c}{$\begin{array}{c}\text { Preoperative CV } \\
\text { diameter, } \mathrm{mm}\end{array}$} & \multicolumn{2}{c}{$\begin{array}{c}\text { Preoperative RA } \\
\text { diameter, mm }\end{array}$} \\
\cline { 2 - 5 } & Mean $\pm(\mathrm{SD})$ & $\begin{array}{c}p- \\
\text { value }\end{array}$ & Mean $\pm(\mathrm{SD})$ & $\begin{array}{c}p- \\
\text { value }\end{array}$ \\
\hline Not on Aspirin & $2.776 \pm(0.27)$ & 0.626 & $2.26 \pm(0.17)$ & 0.218 \\
On Aspirin & $2.828 \pm(0.25)$ & & $2.18 \pm(0.19)$ & \\
\hline
\end{tabular}

Maturation of arteriovenous fistula was assessed by duplex $\mathrm{u} / \mathrm{s}$ with measurement of vein diameter, flow volume, and depth of the vein from the skin. Measurement was taken two weeks and six weeks post-operatively.

The two weeks post-operatively mean vein diameter of aspirin group was $3.876 \mathrm{~mm} \pm 0.456$ and that of the control group was $4.036 \mathrm{~mm} \pm 0.573$ and a $p$-value $=0.284$. The six weeks post - operatively mean vein diameter of aspirin group was $5.86 \mathrm{~mm} \pm 0.342$ and that of the control group was $5.992 \mathrm{~mm} \pm 0.287$ and a $p$-value $=0.284$ (Table 3 , Fig. 1).

Table (3): Comparison between groups according to postoperative vein diameter.

\begin{tabular}{|c|c|c|c|c|}
\hline \multirow[t]{2}{*}{ Variables } & \multicolumn{2}{|c|}{$\begin{array}{c}\text { Vein diameter } \\
2 \text { weeks } \\
\text { postoperative, } \mathrm{mm}\end{array}$} & \multicolumn{2}{|c|}{$\begin{array}{c}\text { Vein diameter } \\
6 \text { weeks } \\
\text { postoperative, mm }\end{array}$} \\
\hline & Mean $\pm(S D)$ & $\begin{array}{c}p- \\
\text { value }\end{array}$ & Mean $\pm(\mathrm{SD})$ & $\begin{array}{c}p- \\
\text { value }\end{array}$ \\
\hline Not on Aspirin & $4.036 \pm(0.573)$ & 0.284 & $5.992 \pm(0.287)$ & 0.097 \\
\hline On Aspirin & $3.876 \pm(0.456)$ & & $5.86 \pm(0.342)$ & \\
\hline
\end{tabular}

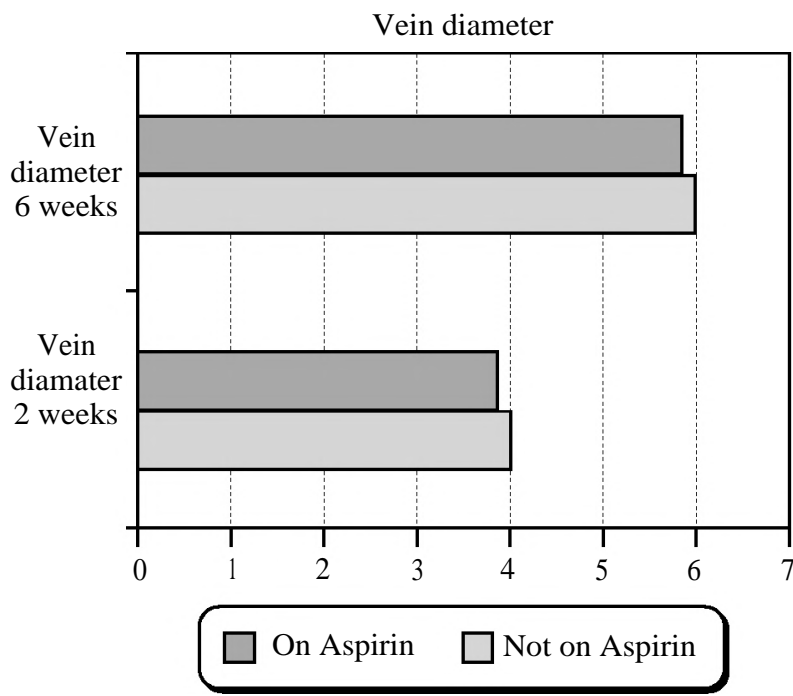

Fig. (1): Comparison between the two groups according to post-operative vein diameter.
According to postoperative depth from the skin, the two weeks post-operatively mean depth from skin of aspirin group was $2.01 \mathrm{~mm} \pm 0.57$ and that of the control group was $2.14 \mathrm{~mm} \pm 0.57$ and a $p$ value $=0.419$. The six weeks post-operatively mean depth from the skin of aspirin group was $1.51 \mathrm{~mm}$ \pm 0.42 and that of the control group was $1.49 \mathrm{~mm}$ \pm 0.35 and $p$-value $=0.869$ (Table 4 , Fig. 2 ).

Table (4): Comparison between groups according to postoperative depth of the vein from skin.

\begin{tabular}{|c|c|c|c|c|}
\hline \multirow{2}{*}{ Variables } & \multicolumn{2}{|c|}{$\begin{array}{c}\text { Depth } 2 \text { weeks } \\
\text { postoperative, } \mathrm{mm}\end{array}$} & \multicolumn{2}{|c|}{$\begin{array}{c}\text { Depth } 6 \text { weeks } \\
\text { postoperative, } \mathrm{mm}\end{array}$} \\
\hline & Mean $\pm(S D)$ & $\begin{array}{c}p- \\
\text { value }\end{array}$ & Mean $\pm(\mathrm{SD})$ & $\begin{array}{c}p- \\
\text { value }\end{array}$ \\
\hline Not on Aspirin & $2.14 \pm(0.57)$ & 0.419 & $1.49 \pm(0.35)$ & 0.869 \\
\hline On Aspirin & $2.01 \pm(0.59)$ & & $1.51 \pm(0.42)$ & \\
\hline
\end{tabular}

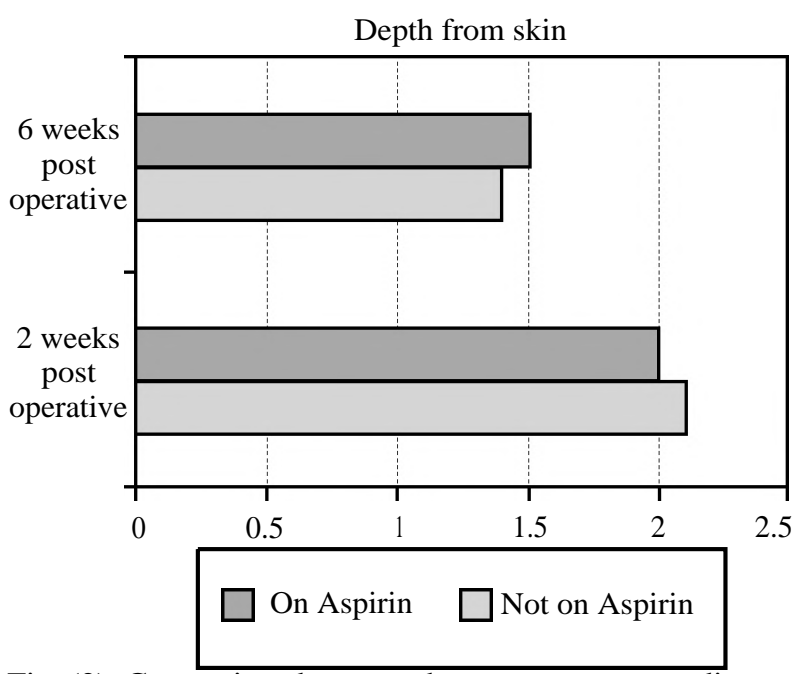

Fig. (2): Comparison between the two groups according to post-operative depth from skin.

The mean flow volume two weeks post-operatively was $634.4 \mathrm{ml} / \mathrm{min} \pm 78.2$ in the aspirin group and $656 \mathrm{ml} / \mathrm{min} \pm 79.8$ in the control group with a $p$-value $=0.303$. After following-up patients six weeks post-operatively, it has been found that the mean flow volume increased and became 780 $\mathrm{ml} / \mathrm{min} \pm 127.2$ in the aspirin group and 754.4 $\mathrm{ml} / \mathrm{min} \pm 128.9$ in the control group with a $p$-value $=0.484$ (Table 5, Fig. 3).

Table (5): Comparison between groups according to postoperative Flow volume.

\begin{tabular}{|c|c|c|c|c|}
\hline \multirow[t]{2}{*}{ Variables } & \multicolumn{2}{|c|}{$\begin{array}{c}\text { Flow volume } \\
2 \text { weeks } \\
\text { postoperative, } \\
\mathrm{ml} / \mathrm{min}\end{array}$} & \multicolumn{2}{|c|}{$\begin{array}{c}\text { Flow volume } \\
6 \text { week } \\
\text { postoperative, } \\
\mathrm{ml} / \mathrm{min}\end{array}$} \\
\hline & Mean $\pm(S D)$ & $\begin{array}{c}p- \\
\text { value }\end{array}$ & Mean $\pm(S D)$ & $\begin{array}{c}p- \\
\text { value }\end{array}$ \\
\hline $\begin{array}{l}\text { Not on Aspirin } \\
\text { On Aspirin }\end{array}$ & $\begin{array}{l}656 \pm(79.8) \\
634.4 \pm(78.2)\end{array}$ & 0.303 & $\begin{array}{l}754.4 \pm(128.9) \\
780 \pm(127.2)\end{array}$ & 0.484 \\
\hline
\end{tabular}




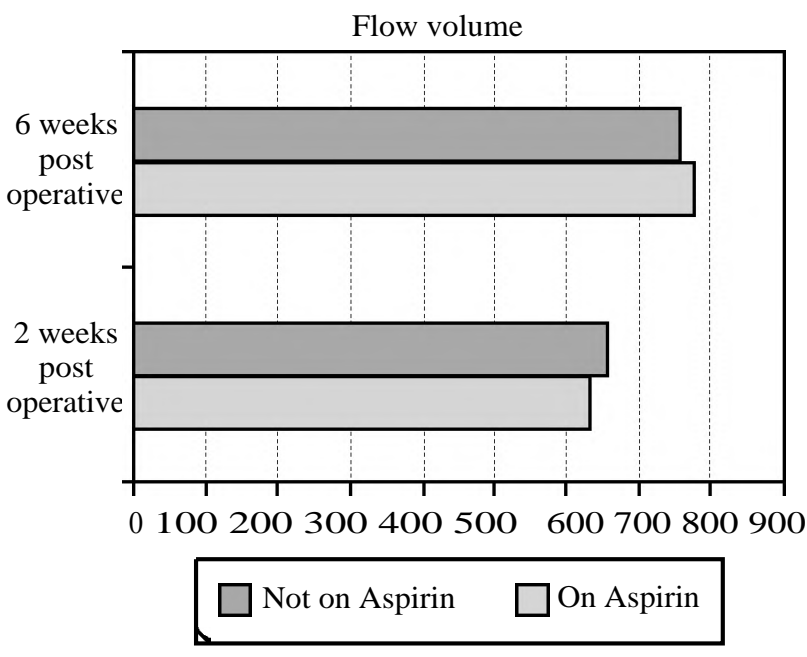

Fig. (3): Comparison between the two groups according to post-operative flow volume.

According to our selected definition of maturation, $96 \%$ of patients developed RC-AVF maturation in Aspirin group in comparison to $92 \%$ in the control group $(p$-value $=0.5743)$.

As regarding post-operative bleeding, three patients $(12 \%)$ in the aspirin group had postoperative bleeding that resolved without treatment, no post-operative bleeding was detected in the control group with a $p$-value $=0.083$. One patient $(4 \%)$ from each group had a mild infection that resolved with antibiotic treatment with a $p$-value of $>0.99$. Access thrombosis has occurred in one patient in the aspirin group and two patients in the control group during the first two weeks due to hypotension on dialysis with a $p$-value of 0.161 (Table 7, Fig. 4).

Table (6): Comparison between groups according to Maturation.

\begin{tabular}{lccc}
\hline & On aspirin & Not on aspirin & $p$-value \\
\hline Maturation & $96 \%(24 / 25)$ & $92 \%(23 / 25)$ & 0.5743 \\
\hline
\end{tabular}

Table (7): Comparison between both groups according to postoperative complications.

\begin{tabular}{lccc}
\hline & $\begin{array}{c}\text { On } \\
\text { aspirin }\end{array}$ & $\begin{array}{c}\text { Not } \\
\text { on aspirin }\end{array}$ & $\begin{array}{c}p \text { - } \\
\text { value }\end{array}$ \\
\hline Bleeding & $3(12 \%)$ & $0(0 \%)$ & 0.083 \\
Infection & $1(4 \%)$ & $1(4 \%)$ & $>0.99$ \\
$\quad \begin{array}{l}\text { Noninfectious fluid } \\
\quad \text { collections }\end{array}$ & $2(8 \%)$ & $3(12 \%)$ & 0.675 \\
$\quad$ Anastomotic complications & $0(0 \%)$ & $0(0 \%)$ & $>0.99$ \\
$\quad$ Mid-AV access/runoff & $0(0 \%)$ & $0(0 \%)$ & $>0.99$ \\
$\quad$ vein complications & $1(4 \%)$ & $2(8 \%)$ & 0.327 \\
$\begin{array}{l}\text { Access thrombosis } \\
\text { Steal syndrome }\end{array}$ & $0(0 \%)$ & $1(4 \%)$ & 0.327 \\
$\quad$ Venous hypertension & $2(8 \%)$ & $1(4 \%)$ & 0.327 \\
$\quad$ Neuropathy & $2(8 \%)$ & $0(0 \%)$ & 0.161 \\
\hline
\end{tabular}

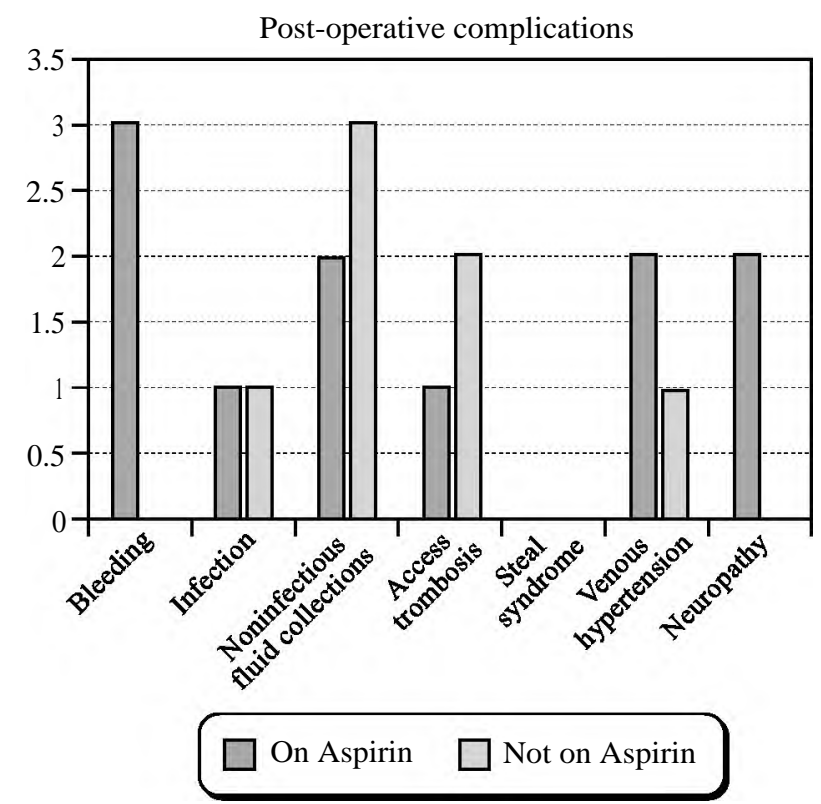

Fig. (4): Comparison between the two groups according to post-operative complications.

\section{Discussion}

This study is a prospective RCT comparing Aspirin intake versus no treatment in patients who had a functioning RC-AVF after finishing creation of the fistula. Patients were divided into 2 groups, the 1 st group (aspirin group)-included 25 patientsreceived Aspirin $75 \mathrm{mg}$ tablet once daily after AVF creation for 6 weeks, while the 2 nd group (control group) did not receive any medication. The two groups were examined clinically and radiologically for fistula maturation after two and six weeks, respectively.

Other studies in the literature that compared aspirin intake versus no treatment or aspirin to other medications or different medications are enlisted in (Table 8).

In the current study, the demographic data findings for each group are summarized in (Table 1 ). The age of the patients ranges from 25 to 88 years with mean age of $55.32 \pm 12.9$ years. This correlates to the study done by Ghorbani A et al., [8] it was undertaken to determine the effects of clopidogrel on the incidence of primary AVF failure among newly created AVFs, however our study was undertaken to determine the effect of aspirin not clopidogrel. The mean age of the patients in the clopidogrel group was $44.23 \pm 3.36$ years and that of the placebo group was $45.8 \pm 2.84$ years with a $p$-value of 0.47 . It correlates also to Rouzrokh $M$ et al., [9] who found in their study that among 390 patients (179 males, 211 females), 22 patients were aged less than 25 years old, and 74 cases 
were above 66 years of age and the rest were aged between these ages. It should be highlighted that Rouzrokh M et al., [9] were talking about the effect of antiplatelet (aspirin and dipyridamole) on patency rate of AVF while we were analyzing the effect of aspirin on the maturation of AVf.

Table (8)

\begin{tabular}{|c|c|c|c|c|}
\hline Study title & Auther name & Year & Groups & Study design \\
\hline $\begin{array}{l}\text { - The Effect of Antiplatelet } \\
\text { Drugs on the Patency } \\
\text { Rate of Arterio-venous } \\
\text { Fistulae in Hemodialysis } \\
\text { Patients }\end{array}$ & $\begin{array}{l}\text { - Rouzrokh M } \\
\text { et al. }\end{array}$ & $\begin{array}{l}\text { - From Sep } 2003 \text { to } \\
\quad \text { Aug } 2007\end{array}$ & $\begin{array}{l}\text { - The first group was treat- } \\
\text { ed with a daily } 100 \mathrm{mg} \text { of } \\
\text { Aspirin. The second } \\
\text { group was treated with a } \\
\text { daily } 75 \mathrm{mg} \text { of dipyrida- } \\
\text { mol. The third group was } \\
\text { treated with placebo. } \\
\text { Each group consisted of } \\
130 \text { patients. }\end{array}$ & $\begin{array}{l}\text { - A Randomized control } \\
\text { Trial. Surgery was } \\
\text { done in Taleghani } \\
\text { Hospital, Kerman- } \\
\text { shah, Iran }\end{array}$ \\
\hline $\begin{array}{l}\text { - Effect of Fish Oil Supple- } \\
\text { mentation and Aspirin } \\
\text { Use on Arteriovenous Fis- } \\
\text { tula Failure in Patients } \\
\text { Requiring Hemodialysis }\end{array}$ & - Irish AB et al. & - From 2008 to 2014 & $\begin{array}{l}\text { - There were } 567 \text { partici- } \\
\text { pants randomized to fish } \\
\text { oil }(n=284) \text { or placebo } \\
(n=283) \text {. There were } 406 \\
\text { participants randomized } \\
\text { to aspirin }(n=203) \text { or pla- } \\
\text { cebo }(n=203) \text {. }\end{array}$ & $\begin{array}{l}\text { - A Randomized Clini- } \\
\text { cal Trial. The study } \\
\text { was done at } 35 \text { dialy- } \\
\text { sis centers in Austral- } \\
\text { ia, Malaysia, New } \\
\text { Zealand, and the Unit- } \\
\text { ed Kingdom. }\end{array}$ \\
\hline $\begin{array}{l}\text { - Consistent aspirin use as- } \\
\text { sociated with improved } \\
\text { arteriovenous fistula sur- } \\
\text { vival among incident he- } \\
\text { modialysis patients in the } \\
\text { dialysis outcomes and } \\
\text { practice patterns study }\end{array}$ & $\begin{array}{l}\text { - Hasegawa T } \\
\text { et al. }\end{array}$ & - From 1996 to 2004 & $\begin{array}{l}\text { - Patients using aspirin at } \\
\text { baseline and one year lat- } \\
\text { er were considered con- } \\
\text { sistent aspirin users. }\end{array}$ & $\begin{array}{l}\text { - An international pro- } \\
\text { spective observational } \\
\text { cohort study of main- } \\
\text { tenance HD patients } \\
\text { being carried out in } \\
\text { four regions (Europe, } \\
\text { Australia and New } \\
\text { Zealand, Japan, and } \\
\text { North America). }\end{array}$ \\
\hline $\begin{array}{l}\text { - Randomized controlled } \\
\text { trial of clopidogrel to pre- }\end{array}$ & $\begin{array}{l}\text { - Ghorbani A } \\
\text { et al. }\end{array}$ & $\begin{array}{l}\text { - From December } 2006 \\
\text { to March } 2008\end{array}$ & $\begin{array}{l}\text { - Clopidogrel ( } 75 \mathrm{mg} / \text { daily) } \\
\text { Vs placebo groub }\end{array}$ & $\begin{array}{l}\text { - Randomized, double- } \\
\text { blind trial }\end{array}$ \\
\hline
\end{tabular}
vent primary arteriovenous fistula failure in hemodialysis patients

- Effect of Clopidogrel on Early Failure of Arteriovenous Fistulas for Hemodialysis

- Dember LM - From 2003 to 2007 - Participants (n= 877) were randomly assigned to receive clopidogrel (300mg loading dose followed by daily dose of $75 \mathrm{mg}$; $\mathrm{n}=441)$ or placebo $(\mathrm{n}=$ 436) for 6 weeks
In the present study there is no gender difference between the two groups and it has been shown that there was no noticeable effect of aspirin on AVF maturation. In accordance with Rouzrokh $\mathrm{M}$ et al., [9] there was no statistically significant difference between (aspirin, dipyridamole and placebo group) on the patency of AVFs among different genders with a $p$-value of 0.2028 between aspirin and placebo group and a $p$-value of 0.2671 between dipyridamole and placebo group.

In the current study, most of the patients were not diabetic in the two groups. Seventeen patients $(68 \%)$ of the aspirin group and nineteen patients
(76\%) of the control group were not diabetics with a $p$-value $=0.161$. This correlates to the study done by Ghorbani A et al., [8] only $15.1 \%$ of the patients in the clopidogrel group and $11.8 \%$ of the patients in placebo group were diabetics. In contrary, Rouzrokh M et al., $8170 \%$ of the patients in aspirin group, $80 \%$ of the patients in dipyridamole group and $70.7 \%$ of the patients in the control group were diabetics. According to Dember LM et al., [5] $49.2 \%$ of patients in the clopidogrel group and $47 \%$ of patients in the placebo group were diabetics. It should be pointed that Dember LM et al., was undertaken to determine the effect of clopidogrel on early failure of arteriovenous fistula (AVF). 
Viecelli AK et al., [10] in their FAVOURED trial, they investigated whether three months of omega3 polyunsaturated fatty acids, either alone or in combination with aspirin, would effectively reduce primary access failure of de novo arteriovenous fistulae. This trial is an international double-blinded RCT conducted in 34 hemodialysis centers in Australia, New Zealand, the United Kingdom and Malaysia. Diabetes mellitus was significantly more prevalent in the Malaysian cohort than (Australia, New Zealand and the United Kingdom) group ( $65 \%$ vs $43 \%, p<0.001)$. The prevalence of diabetes mellitus was highest in participants underwent AVG surgery (53\%) compared to participants who underwent an AVF (46\%) but there was no clearly obvious difference between both groups regarding diabetes.

In the present study, the fistula was created in the non-dominant hand of 15 patients $(60 \%)$ in the aspirin group and 12 patients (48\%) in the control group. According to Rouzrokh $\mathrm{M}$ et al., [9] the fistula was created in the non-dominant hand of 60 patients $(68.1 \%)$ in the aspirin group and 63 patients $(76.6 \%)$ in the dipyridamol group.

In the current study, the mean preoperative vein diameter in both groups was $(2.828 \pm 0.25$ in aspirin group and $2.776 \pm 0.27$ in the control group) and this was associated with functional maturation in both groups. This is because of the restrictive selection of the patients and the good preoperative mapping. In this regard, Siddiqui $\mathrm{M}$ et al., [11] they also found that the preoperative vein diameter greater than $2.5 \mathrm{~mm}$ resulted in a fivefold increase in fistula maturation as compared to vein diameter less than $2.5 \mathrm{~mm}$. According to Mendes et al., [12] they reported that when the diameter of the cephalic veins exceeded $2 \mathrm{~mm}$, there was a $76 \%$ success rate of functional dialysis access, whereas, if the diameter was less than $2 \mathrm{~mm}$, there was only a $16 \%$ success rate. Khavanin $\mathrm{M}$ et al., [13] also mentioned that the maturation of the fistula showed significant correlation with the preoperative mean diameter of vein which was $2.40 \mathrm{~mm} \pm 0.79$.

No previous studies have discussed the effect of drugs like (aspirin, ticlopidine, dipyridamole, dipyridamole plus aspirin, warfarin, fish oil, clopidogrel, and sulfinpyrazone) on post-operative flow volume, depth from the skin and vein diameter and their association with functional maturation.

In this study, the two weeks post-operatively mean flow volume was $634.4 \mathrm{ml} / \mathrm{min} \pm 78.2$ in the aspirin group and $656 \mathrm{ml} / \mathrm{min} \pm 79.8$ in the control group. After following-up patients six weeks post- operatively it has been found that the mean flow volume increased and became $780 \mathrm{ml} / \mathrm{min} \pm 127.2$ in the aspirin group and $754.4 \mathrm{ml} / \mathrm{min} \pm 128.9$ in the control group. According to Robbin ML et al., [14] fistula adequacy for dialysis had been doubled if the minimum venous diameter was $0.4 \mathrm{~cm}$ or greater and this was found in 24 patients out of 27 representing $89 \%$ of the patients included in their study. They have also emphasized that fistula adequacy for dialysis had been doubled if flow volume was $500 \mathrm{~mL} / \mathrm{min}$ or greater and this was found in 26 patients out of 31 representing $84 \%$ of the patients included in their study. According to Ives CL et al., [15] access blood flow volume of $500 \mathrm{ml} / \mathrm{min}$ and AVF diameter of $4 \mathrm{~mm}$ eight weeks post-operative are needed to support dialysis. AbdElmageed MK et al., [16] followed-up 100 patients for six months, they encountered 18 failed cases while there were 82 mature fistula. The blood flow was considerably lower in the failed fistulas than that in the mature fistulas at early postoperative period $(p$-value $=0.001)$. The cutoff value was $200.5 \mathrm{ml} / \mathrm{min}$. This matches to results of the study done by Ladenheim ED et al., [17] who concluded that blood flow $<200 \mathrm{~mL} / \mathrm{min}$ at the 1 -week postoperative was associated with failed maturation of the fistula.

The overall incidence of bleeding events was $12 \%$ in this study, three patients in the aspirin group had postoperative bleeding that resolved without treatment. According to Dember LM et al., [5] the frequency and the severity of bleeding events were not greater among participants treated with clopidogrel than among those who received placebo with $(p>0.99 \%)$. According to Viecelli AK et al., [10] in order to minimize the risk of bleeding, a lower dose of aspirin (100mg) was used in the FAVOURED trial. Low dose aspirin, while not associated with increased bleeding, did not reduce the frequency of access thrombosis during the first 12 months of AVF creation.

Regarding infection only one patient (4\%) from each group had infection that resolved with antibiotic treatment. According to Padberg et al., [18] the reported incidence of infections affecting the $\mathrm{AV}$ access site ranges from $0.56 \%$ to $5 \%$ per year for autogenous AV access. Infection may respond to antibiotics. If associated with bleeding, then ligation proximal to the anastomosis may be required. In this study, there is no statistically significant difference between the two groups regarding maturation. There was one case of access thrombosis in the aspirin group and two cases the control group $(p=0.327)$. 
In the current study, after Six weeks of followup of all patients, maturation occurred in $94 \%$ of patients. The maturation rate in Apirin group was $96 \%$, while it was $92 \%$ in control group with a $p$ value of 0.5743 . This correlates to the study done by Irish AB, [19] he found that the risk of fistula failure was similar between the aspirin and placebo arms (87 of 194 [45\%] vs 83 of 194 [43\%]; $p=.68$ ). On the contrary, according to Hasegawa T et al., [20] consistent aspirin use was significantly related to a lower risk of final AVF failure ( $p$-value $=0.07$ ).

\section{Limitation of the study:}

The sample size was relatively small. Because we chose the patients according to specific criteria that exclude most of the available cases.

The second limitation was the relative short duration of follow-up. The study focused on the immediate outcome of maturation and not on longterm survival, as we followed-up the patients at two and six weeks post-operatively.

\section{Conclusion:}

Aspirin use is not beneficial for AVF maturation among ESRD patients who undergo a new AVF. That's why practice patterns in this area needs to be improved to limit unbeneficial aspirin use. Good preoperative mapping of AVF results in better AVF patency and maturation. Cephalic vein diameter of more than $2.5 \mathrm{~mm}$ and radial artery diameter more than $2 \mathrm{~mm}$ will be recommended for better maturation of AVF.

\section{Financial support and sponsorship:}

Nil.

\section{Conflict of interst:}

There are no conflicts of interest.

\section{References}

1- BASHAR K., CONLON P.J., KHEIRELSEID E.A., et al.: Arteriovenous fistula in dialysis patients: Factors implicated in early and late AVF maturation failure. The surgeon: J. R Coll. Surg., 2016.

2- DUNN J., HERSCU G. and WOO K.: Factors influencing maturation time of native arteriovenous fistulas. Annals of Vascular Surgery, 29 (4): 704-707, 2015.

3- TANNER N.C. and da SILVA A.F.: Medical Adjuvant Treatment to Improve the Patency of Arteriovenous Fistulae and Grafts. J. Vasc. Endovasc. Surg., 52: 243-252, 2016.

4- SIDAWY A.N., SPERGEL L.M., BESARAB A., et al.: The Society for Vascular Surgery: Clinical practice guidelines for the surgical placement and maintenance of arteriovenous hemodialysis access. J. Vasc. Surg., 48: 2Se25S, 2008.
5- Dember L.M., Beck G.J. and A.M.: Effect of Clopidogrel on Early Failure of Arteriovenous Fistulas for Hemodialysis. JAMA, 299: 2164-2171, 2016.

6- VANE J.R. and BOTTING R.M.: The mechanism of action of aspirin. Thromb. Res. Jun., 15; 110 (5-6): 255-8, 2003.

7- LOCHAM S., BEAULIEU R.J., DAKOUR-ARIDI H., NEJIM B. and MALAS M.B.: Role of antiplatelet therapy in the durability of hemodialysis access. J. Nephrol., 31: 603-611, 2018, .

8- GHORBANI A., AALAMSHAH M., SHAHBAZIAN H., EHSANPOUR A. and AREF A.: Randomized controlled trial of clopidogrel to prevent primary arteriovenous fistula failure in hemodialysis patients, 19: 57-62, 2009.

9- ROUZROKH M., REZA M. and REZA A.: The Effect of Antiplatelet Drugs on the Patency Rate of Arterio-venous Fistulae in Hemodialysis Patients, 9: 451-457, 2010.

10- VIECELLI AK and PASCOE E.M., P.K.: Baseline characteristics of the omega-3 fatty acids (Fish oils) and Aspirin in Vascular access OUtcomes in REnal Disease (FAVOURED) study. APSN, 21: 217-228, 2016.

11- SIDDIQUI1 M., ASHRAFF S., SANTOS D., et al.: Predictive parameters of arteriovenous fistula maturation in patients with end-stage renal disease. Kidney Res. Clin. Pract, 37: 277-286, 2018.

12- MENDES R.R., FARBER M.A., MARSTON W.A., DINWIDDIE L.C., KEAGY B.A. and BURNHAM S.J.: Prediction of wrist arteriovenous fistula maturation with preoperative vein mapping with ultrasonography. J. Vasc. Surg., 36: 460-463, 2002.

13- KHAVANIN ZADEH M., GHOLIPOUR F., NADERPOUR Z. and PORFAKHARAN M.: Relationship between vessel diameter and time to maturation of arteriovenous fistula for hemodialysis access. Int. J. Nephrol., 2012: 942950, 2012.

14- ROBBIN M.L., CHAMBERLAIN N.E., LOCKHART M.E., GALLICHIO M.H., YOUNG C.J., DEIERHOI M.H., et al.: Hemodialysis arteriovenous fistula maturity: US evaluation. Radiology, 225: 59e64, 2002.

15- IVES C.L., AKOH J.A., GEORGE J., VAUGHANHUXLEY E. and LAWSON H.: Preoperative vessel mapping and early post-operative surveillance duplex scanning of arteriovenous fistulae. J. Vasc. Access, 10: 37e42, 2009.

16- ABD-ELMAGEED M.K., ELSAYED B.F., ELKHOLY M.R., et al.: Role of early postoperative ultrasonography in prediction of AV fistula failure in hemodialysis patients Egyptian Journal of Radiology and Nuclear Medicine, 51: 95, 2020.

17- LADENHEIM E.D., et al.: First-week postoperative flow measurements are highly predictive of primary patency of radiocephalic arteriovenous fistulas. Nathan Chadwick Ladenheim Dialysis Access Centers, Fresno, Cali.

18-PADBERG Jr., SIDAWY A.N., SPERGEL L.M., BESARAB A., ALLON M., JENNINGS W.C., F.T. and MACSATA R.A.: Complications of arteriovenous hemodialysis access: Recognition and management. Journal of Vascular Surgery, 48 (5): S2-S25, 2008.

19- IRISH A.B.: Effect of Fish Oil Supplementation and Aspirin Use on Arteriovenous Fistula Failure in Patients Requiring Hemodialysis. JAMA Intern. Med., 177 (2): $184,2017$. 
20- HASEGAWA SHAHANI S and MAROLI S., et al.: Consistent Aspirin Use Associated with Improved Arteriovenous Fistula Survival among Incident Hemo- dialysis Patients in the Dialysis Outcomes and Practice Patterns Study. Journal of the American Society of Nephrology.

\section{دراسة تأثير عقار الأسبرين على نضج الوصلة الشريانية الورديدية

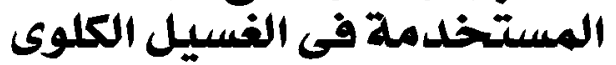

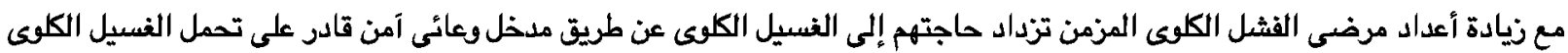

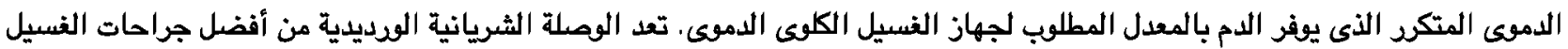

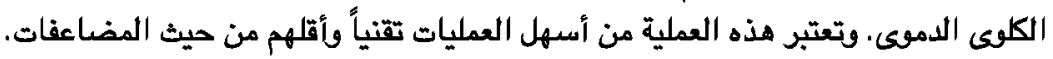

تعد الوصلة الشريانية الويدية بين الشريان الكعبرى والوريد الرأسى الضيار الأفل اللغسيل الكلوى الد موى. ولأن الوصلة الشريانية هامة

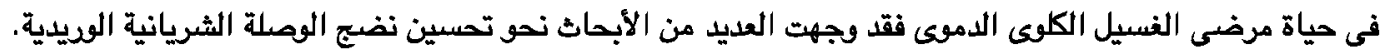

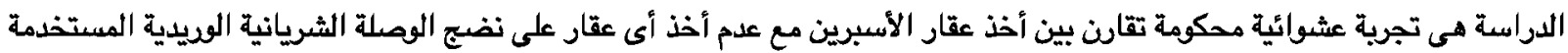

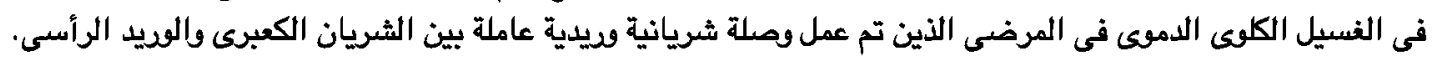

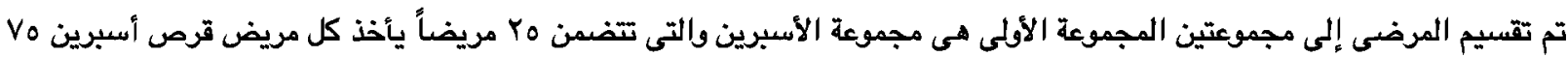
مجم يومياً لمدة ستة أسابيع من عمل الوصلة الثريانية الوديدية، والمجموعة الثانية لم تتلقى أية أدوية.

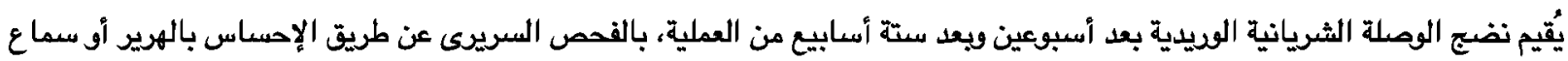

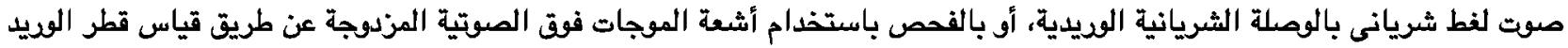
وعمق الوريد من الجلد وحجم الدم المتدفق بالوريد.

لم يوجد فى دراستنا أى أختلاف إحصائى ملحوظ بين المجموعتين بخصوص تأثيثر عقار الأسبرين على نضج الوصلة الثريانية الوديدية المستخدمة فى الفسيل الكلوى الدموىى.

وجلت بعض المضاعفات فى المجموعتين ومنها تجلط الوصلة الشريانية الوريدية فى مريض واحد في المجموعة الأولى (مجموعة الأسبرين)

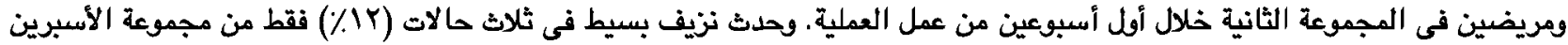

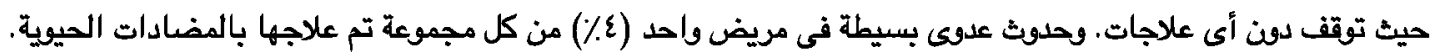

